\title{
FALLEN FROM GRACE: FROM CHERISHED GARDEN DWELLERS TO INVASIVE SPECIES. THE STORY OF TWO GARDEN-ESCAPED VINES IN MADEIRA ISLAND
}

\author{
Aida Pupo-Correia*, Miguel Menezes de Sequeira** \\ José Tadeu Aranha***
}

\begin{abstract}
Cardiospermum grandiflorum Sw. and Podranea ricasoliana (Tanfani) Sprague were introduced after 1930s to be used for arbours and pergolas in gardens sited in warmer locations under 400 metres in south coast of Madeira Island. At the present they become very common and are densely growing over wastelands, stone walls, along stream banks, and over forsaken terraces. The historical expansion of these vines was evaluated using Repeat Landscape Photography Technique (RLPT). These species, which expanded in potential areas of Mayteno umbellatae-Oleo maderensis sigmetum (series of microforest of Madeiran oleaster tree) and Semele androgynae-Apollonio barbujanae sigmetum (series of laurel forest of barbusano-tree), spread into former agricultural lands and areas previously occupied by native vegetation or that could allow its regeneration. Although the evidence of being a threat to native vegetation recovery, no attempt has been made, up till now, to control them.

KEYwORDs: alien plant, invasive plant, fast-growing vine, garden escapee, repeat landscape photography technique.

\author{
CAIIDAS EN DESGRACIA: DE APRECIADOS HABITANTES DEL JARDÍN A \\ ESPECIES INVASORAS. LA HISTORIA DE DOS ENREDADERAS ESCAPADAS \\ DEL JARDÍN EN LA ISLA DE MADEIRA
}

\section{RESUMEN}

Cardiospermum grandiflorum Sw. y Podranea ricasoliana (Tanfani) Sprague fueron introducidas después de 1930 para ser utilizadas en los jardines y pérgolas de las zonas inferiores a $400 \mathrm{~m}$ de altitud de la costa meridional de Madeira. En la actualidad son muy frecuentes, creciendo de forma muy densa sobre muros de piedra, cauces de aguas o terrazas de cultivos abandonados. Se ha evaluado la expansión histórica de estas enredaderas utilizando la técnica de la fotografía paisajística repetida. Estas especies, que se expanden en el área potencial del Mayteno umbellatae-Oleo maderensis sigmetum (series de microbosques del acebuche de Madeira) y en el del Semele androgynae-Apollonio barbujanae sigmetum (series de laurisilva de barbusano), se expanden en antiguas áreas agrícolas y en áreas previamente ocupadas por vegetación nativa o que podrían propiciar su regeneración. Pese a que es evidente que son una amenaza para la recuperación de la vegetación nativa, hasta el momento actual no se han desarrollado planes para su control.

PAlabras Clave: plantas exóticas, plantas invasoras, enredaderas de crecimiento rápido, escapadas de jardines, técnica de repetición de fotografía paisajística. 


\section{INTRODUCTION}

Cardiospermum grandiflorum Sw. and Podranea ricasoliana (Tanfani) Sprague were introduced in the first half of the $20^{\text {th }}$ century to be used for arbours and pergolas in gardens located in warmer locations under 400 metres in south coast of Madeira Island (Vieira 2002). C. grandiflorum, is a species native to tropical America, extending from the Southern Mexico to the South American territories and tropical Africa, although there is certain degree of uncertainty about the latter status (Chapman et al. 2017). In Madeira Island it was been pointed out by Grabham (1934) as cultivated plant, identified then as the very similar and closely related species C. halicacabum L. (Vieira 2002), and considered as naturalised in late 1960s (Hansen 1968). It was also introduced in early $20^{\text {th }}$ century in many other regions as South Africa, Australia, some regions in the Mediterranean area and Canary Islands, where the species also become established and considered invasive (Chapman et al. 2017) being currently included in the list of 100 most invasive species in Macaronesia (Silva et al. 2008) and one of 100 most invasive species of the world (Global Invasive Species Database 2019).

Podranea ricasoliana, a popular garden plant across de world, is native of Tropical East and South Africa (Bidgood et al. 2006). The species was probably introduced in Madeira after late 1940s, since it was not referred by Grabham (1942). Being an extremely vigorous climber and drought resistant in addition to gardening activities it was also used to support soil and banks, mainly in Funchal and surroundings (Vieira 2002) becoming naturalised in mid-1970s (Vieira 1974). Although not included in the lists of the most invasive plants, mentioned above, this species is considered an invasive garden-escape in areas where it was also introduced as ornamental plant as Australia, New Zealand (Malan and Notten 2002) and Hawaii (HEAR 2013).

Invasive alien species are a menace to native ecosystems and biodiversity having significant ecological and socioeconomic impacts throughout the world and particularly on islands, due to their vulnerability to the effects of non-native species. Attempts to eradicate or control them have high uncertainty and barriers to their success are in general related to human unwillingness rather than scientific and technologic constraints (Reaser et al. 2007).

The aim of this paper was to assess the historical expansion of these two invasive vines gathering information of the dynamics of these two species, and, the-

* Madeira Botanical Group (GBM), Faculty of Life Sciences, Universidade da Madeira, Funchal, Portugal. Corresponding author: aidapupo@sapo.pt.

** Madeira Botanical Group (GBM), Faculty of Life Sciences, Universidade da Madeira, Funchal, Portugal.

*** Centre for the Research and Tecnology of Agro-Environmental and Biological Sciences (CITAB) - UTAD, University of Trás-os-Montes e Alto Douro, Vila Real, Portugal. 
refore, contribute for future studies that intend to perceive the pattern of these two species for better control strategies.

\section{METHODS}

The historical evolution was evaluated using 200 historic (1875-1950) and recent (2006-2013) photographs produced with RLPT (Repeat Landscape Photography Technique), ranging from 56 to 131 years of time interval assessed. The historical photographs were digitised into 8-bit grey-scale images in TIFF format. The replicated photographs of the historical photographs [large format, high resolution (TIFF quality)] were acquired from the same point and camera axis orientation, with a Cannon EOS 60D camera equipped with EF-S 17-85 IS VS11 lens. After finding the general location of the landscape photographed, placing the camera in the exact position and height above ground was achieved by using a coarse "cross-hair" grid drawn on a printed copy to compare the view and to line up features, on the right and on the left, and in the foreground and background (Malde 1973). Image orientation was established by the intersection of the lines that cross the fiducial marks [a simplification of the aerial photography method to identify the principal point (Lillesand and Kiefer 1994). For further detail see Pupo-Correia et al. (2014). Because this research aimed to quantitatively evaluate changes, images within each photo-pair were co-referenced to each other and were analysed by remote sensing and geographic information system technologies (ArcGIS 9.3). A Georeference tool was used to place landscape features in same coordinates in both images, with at least four control points (root mean square error $\leq 0.05$ pixel). The same software was used to classify landscape features by creating vector files, with polygons representing distinct land coverage types (supervised classification). To quantify the alteration, shapefiles of the sampled areas of each photo-pair were intersected (Intersect tool). This new shapefile enabled to get information about features or portions of features that overlap, to calculate geometric relationships between them (Calculate Geometry tool) and to create a contingency table for statistical changes analysis. The area values that were calculated meant to quantify the changes in image cover and not to measure the real surface area.

\section{RESULTS AND DISCUSSION}

Ornamental plants introduced in domestic gardens, as it is worldwide recognised, make up the majority of the most successful invasive species. Plant traits making them suitable for gardening, plus careless environmental practices in management of domestic gardens are important circumstances in the invasion success of alien species (Dehnen-Schmutz et al. 2007; Pyšek and Richardson 2007; Dawson et al. 2008; Guo et al. 2019), as it is the case of these two species (Malan and Notten 2002; Chapman et al. 2017). 

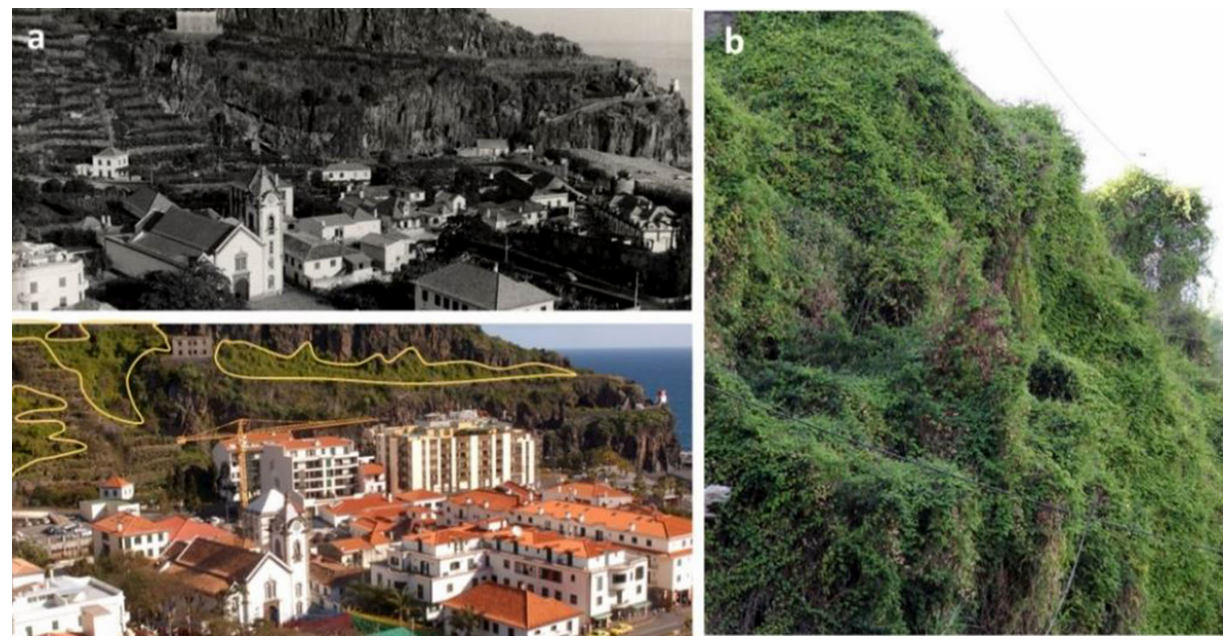

Figure 1. (a) Landscape zoom of historical and repeated landscape photographs taken in Ribeira Brava in early $20^{\text {th }}$ century (by unknown photographer, ARM) and in 2010 (AP,MS), highlighted polygons correspond to areas were Cardiospermum grandiflorum $\mathrm{Sw}$. was seen in current landscape; (b) A 'curtain infestation' of C. grandiflorum over a stream bank. Funchal, south coast, 2015 (AP).

Neither of the two species were identified in historical landscape, in accordance with the information about the time they were given as naturalised plants. $C$. grandiflorum and $P$. ricasoliana were the vines more often seen in photographed landscape (40/200, compared to 7/200 photographs showing all other naturalised vines). In the present landscape, they were more often detected in photographs of southern coastal regions (32, compared to 8 in the north coast) as the distribution referred by Short (1994) and Vieira (2002) i.e., mainly south coast up to 400 metres (a.s.l.). Results have shown that although the C. grandiflorum invaded different environments, it greatly overran lands that were no longer farmed, especially in southern areas (Figure 1a, 3), forming dense patches of balloon-vines growing together (Figure 1b). P. ricasoliana have shown major predominance in Funchal urban area where it grows profusely over the steep rocky banks of main streams crossing the valley (Figure $2 \mathrm{~b}$ ). On the north coast they were also seen rambling over abandoned terraces and native vegetation.

Both species were seen spreading over potential areas of Madeiran oleaster tree and barbusano-tree vegetation series (Figure 2a, 3). These areas have been occupied since the early days of colonial settlement by agriculture and construction and plant communities of the seral stages are rare, solely occurring in small isolated patches (Menezes de Sequeira et al. 2007). Due to the ability of vines to compete by stifling and killing non-climbing plants, the presence of these species in areas where native vegetation recovered, or could allow its regeneration, can block 

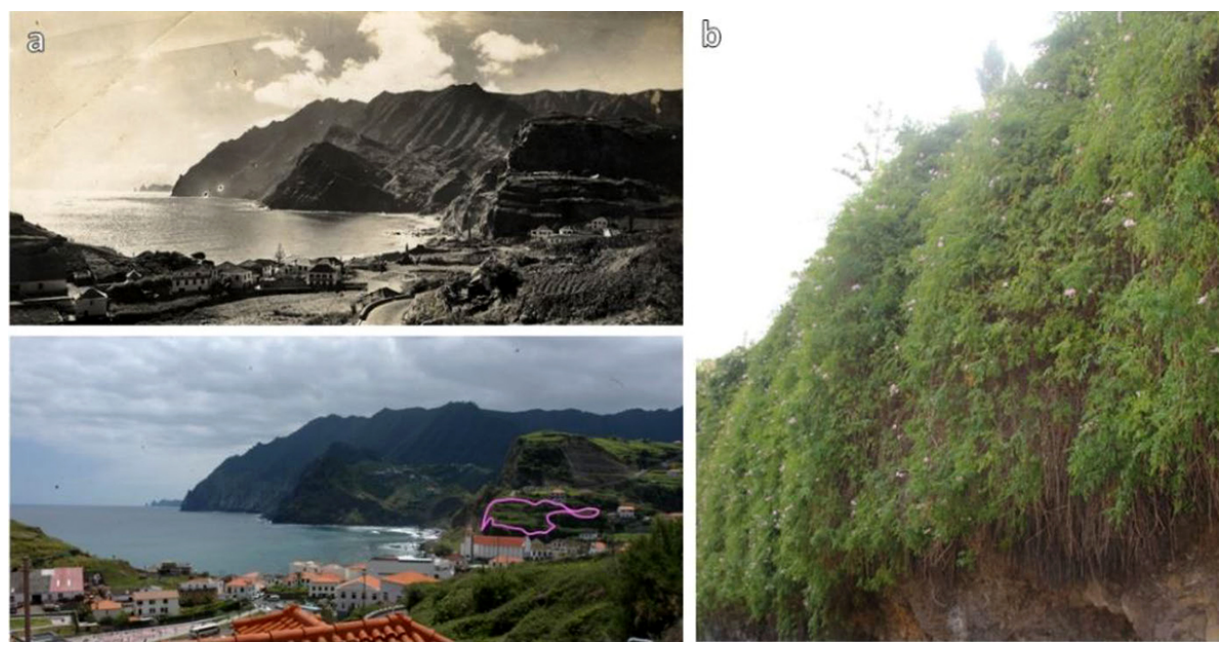

Figure 2. (a) Landscape zoom of historical and repeated landscape photographs taken in Porto da Cruz in early $20^{\text {th }}$ century (by unknown photographer, ARM) and in 2012 (AP, MS), highlighted polygon correspond to the area were Podranea ricasoliana (Tanfani) Sprague was seen in current landscape; (b) P. ricasoliana which densely covers a cliff preventing any other vegetation growth. Funchal, 2015 (AP).

native vegetation development for decades or completely change the direction of native forest succession (Paul and Yavitt 2010). In addition, C. grandiflorum is included in several lists of most invasive species, in Macaronesia as worldwide (Silva et al. 2008; Chapman et al. 2017), and P. ricasoliana was indicated as invasive species (HEAR 2013) as well. Although these two species were not assessed as dominant/moderate invaders in a comparison of plant invasions in 30 archipelagos all over the world (Kueffer et al. 2010), same study have shown that alien plants with invasive behavior in other islands are much more likely to become invasive than any other naturalised species. For these reasons, these two taxa must be taken as a major threat to native vegetation and biological diversity and ought be submitted to eradication and control, as it has been carried out in some other places where this smothering species it is also a hard-hitting invasive plant (Foxcroft et al. 2008; Foxcroft et al. 2013). However, up till now, no attempt was made to control them in Madeira Island (Silva et al. 2008).

\section{CONCLUSION}

C. grandiflorum and P. ricasoliana expanded in potential areas of Mayteno umbellatae-Oleo maderensis sigmetum and Semele androgynae-Apollonio barbujanae sigmetum, spreading from gardens into former agricultural lands and barren areas, 


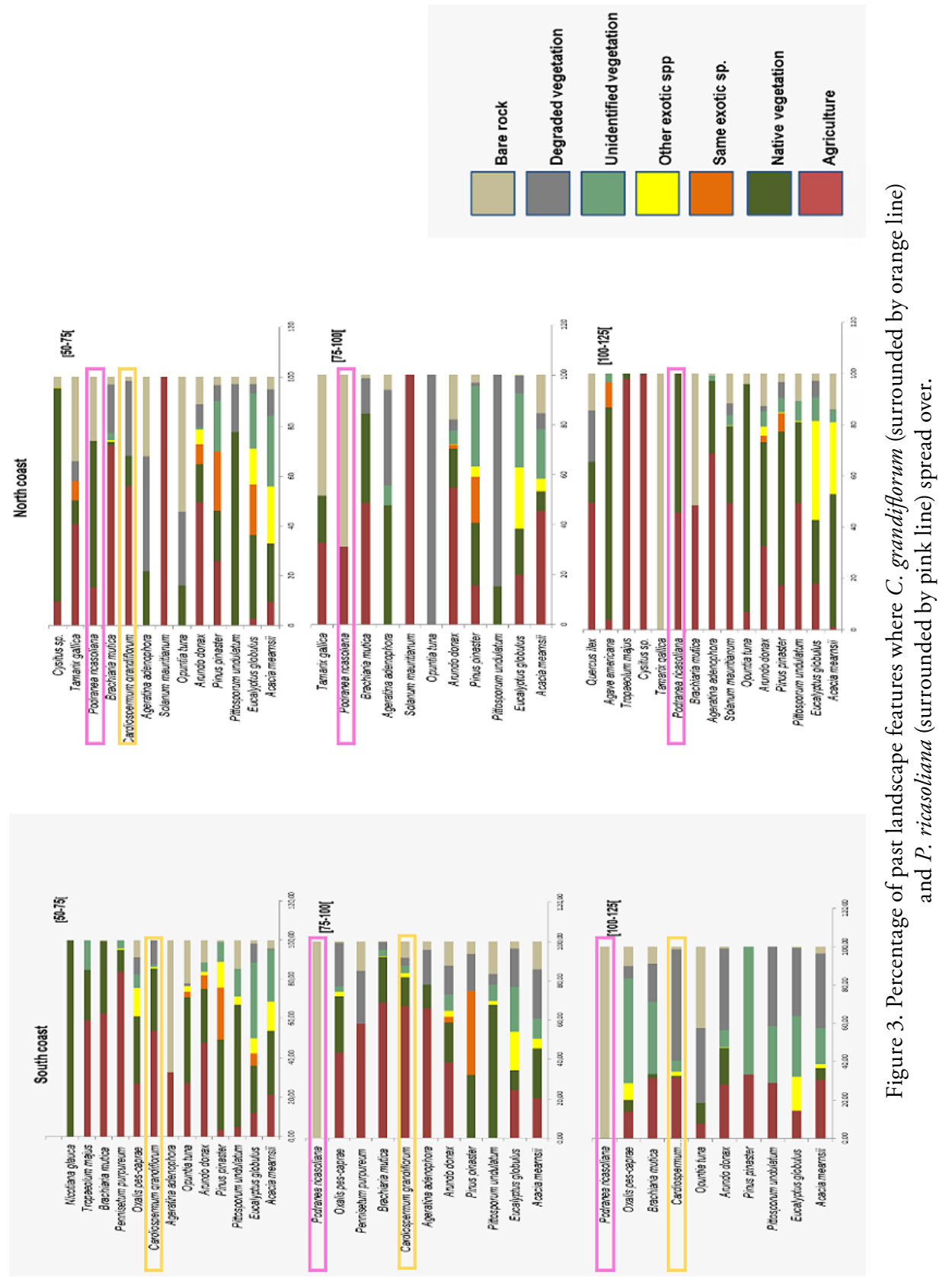


preventing native vegetation regeneration and smothering the one that has recovered. Since these invasive alien species can cause serious damage to biological diversity it is the utmost interest to develop measures to control them, as it has been carried out in some other places, where these smothering species are also hard-hitting invasive plants.

\section{AUTHOR'S CONTRIBUTION}

Conceived the idea and carried out the field work: A.P.-C. and M.M.S.

Proposed and verified the analytical methods: J.A.

Performed the analysis, drafted the manuscript and designed the figures: A.P.-C.

Discussed the results and contributed to the final manuscript: All authors.

ReCibIDo: octubre de 2019; ACEPTADO: marzo de 2020 


\section{REFERENCES}

Bidgood, S., Verdcourt, B. and Vollesen, K. 2006. Bignoniaceae. In: Beentje, H.J. and Ghazanfar, S.A. (eds.) Flora of Tropical East Africa. London: Kew Royal Botanic Gardens pp. 1-53.

Chapman, D., Brundu, G., Roux, J.L., Pescot, O. and tanner, R. 2017. Cardiospermum grandiflorum. Bulletin OEPP/EPPO 47: 526-530.

Dawson, W., Mndolwa, A.S., Burslem, D.R.P. and Hulme, P.E. 2008. Assessing the risks of plant invasion arising from collections in tropical gardens. Biodivers Conserv. 17: 1979-1995.

Dehnen-Schmutz, K., Touza, J., Perrings, C. and Williamson, M. 2007. A century of the ornamental plant trade and its impact on invasion success. Diversity Distrib. 13: 527-534.

Foxcroft, L.C., Pyšex, P., Richardson, D.M. and Genovesi, P. (eds.) 2013. Plant invasions in protected areas. Patterns, Problems and Challenges. Dordrecht: Springer 656 pp.

Foxcroft, L.C., Richardson, D.M. and Wilson, J.R.U. 2008. Ornamental Plants as Invasive Aliens: Problems and Solutions in Kruger National Park, South Africa. Environ. Manage. 41: 32-51.

Global Invasive Species Database (GISD) 2019. Species profile: Cardiospermum grandiflorum, Global Invasive Species Database. Retrieved from http://193.206.192.138/gisd/speciesname/Cardiospermum+grandiflorum.

Grabham, M. 1934. Plants seen in Madeira. A handbook of botanical information for visitors and intending residents. London: H.K. Lewis.

Grabham, M. 1942. Madeira. Its flowering plants and ferns. London.

Guo, W.Y., Kleunen, M.V., Pierce, S., Dawson, W., Essl, F., Kreft, H., Maurel, N., Pergl, J., Seebens, H., Weigelt, P. and Pyšek, P. 2019. Domestic gardens play a dominant role in selecting alien species with adaptative strategies that facilitate naturalization. Global Ecol. Biogeogr. 00: 1-12.

Hansen, A. 1968. Floristiche Beobachtungen auf der Inseln Madeira. Bocagiana 15: 1-11.

HEAR 2013. Podranea ricasoliana (Bignoniaceae), WRA Species Report, Hawaiian Ecosystems at Risk Project. Available from http://www.hear.org/Pier/wra/pacific/Podranea\%20ricasoliana.pdf.

Kueffer, C., Daehler, C.C., Torres-Santana, C.W., Lavergne, C., Meyer, J.-Y., Otto, R. and Silva, L. 2010. A global comparison of plant invasions on oceanic Islands. Perspect. Plant Ecol. Syst. 12: 145-161.

Lillesand, T.M. and Kiefer, R.W. 1994. Remote Sensing and Image Interpretation. $3^{\text {rd }}$ ed. New York: John Wiley and Sons 736 pp.

Malan, C. and Notten, A. 2002. Podranea ricasoliana (Tanf.) Sprague. PlantsAfrica.com. Available from http://pza.sanbi.org/podranea-ricasoliana.

MALde, H.E. 1973. Geologic bench marks by terrestrial photography. Journal of Research of the United States Geological Survey 1: 193-206.

Menezes de Sequeira, M., Jardim, R. and Capelo, J. 2007. A chegada dos portugueses às ilhas o antes e o depois (Madeira). In: Silva, J.S. (ed.) Árvores e Florestas de Portugal. Vol. 6: Açores e Madeira. Lisboa: Público, Comunicação Social SA e Fundação Luso-Americana para o Desenvolvimento pp. 165-194

Paul, G.S. and Yavitt, J.B. 2010. Tropical Vine Growth and the Effects on Forest Succession: A Review of the Ecology and Management of Tropical Climbing Plants. Bot. Rev. 77: 11-30. 
Pupo-Correia, A., Menezes de Sequeira, M. and Aranha, J.T. 2014. Landscape repeat photography: Solutions to improve efficiency of a useful tool for vegetation research. Silva Lusit., n. ${ }^{\circ}$ Especial: 117-130.

PyšeK, P. and Richardson, D.M. 2007. Traits Associated with Invasiveness in Alien Plants: Where Do we Stand? In: Nentwig, W. (ed.), Biological Invasions. Ecological Studies (vol. 196), Verlag Berlin Heidelberg: Springer. pp. 97-126.

Reaser, J.K., Meyerso, L.A., Cronk, Q., Poorter, M.D., Eldredge, L.G., Green, E., Kairo, M., Latasi, P., Mack, R.N., Mauremootoo, J., O’Dowd, D., Orapa, W., Sastroutomo, S., Saunders, A., Shine, C., Thrainsson, S. and Vaiutu, L. 2007. Ecological and socioeconomics impacts of invasive alien species in island ecosystems. Environ. Conserv. 34: 98-111.

Short, M.J. 1994. Sapindaceae. Cardiospermum L. In: Press, M.J. (ed.). Flora of Madeira, London: HMSO pp. 211-212.

Silva, L., Land, E.O., Rodríguez Luengo, J.L., Borges, P., Oliveira, P. and Jardim, R. 2008. Invasive alien species. In: Silva, L., Land, E.O. and Rodríguez Luengo, J.L. (eds.). Invasive Terrestrial Flora and Fauna of Macaronesia. TOP 100 in Azores, Madeira and Canaries. Ponta Delgada: ARENA pp. 159-165.

Vieira, R. 1974. Flowers of Madeira. Funchal: Francisco Ribeiro 124 pp.

Vieira, R 2002. Flora da Madeira. Plantas Vasculares Naturalizadas no Arquipélago da Madeira. Bol. Mus. Munic. Funchal 8: 5-281. 
